\title{
Influence of heat pumps inclusion in deaeration scheme of heating network make-up water on the operating modes of the TPP
}

\author{
Irina Anikina ${ }^{1, *}$, Vyacheslav Suslov ${ }^{2}$ \\ ${ }^{1}$ Peter the Great St.Petersburg Polytechnic University, Polytechnicheskaya 29, St. Petersburg, 195251, \\ Russian Federation \\ ${ }^{2}$ St. Petersburg State Technological University of Vegetable Polymers, ul. Ivana Chernykh 4, Russian \\ Federation
}

\begin{abstract}
The idea of using a heat pump in the heating cycle seems quite attractive at first glance, but requires careful analysis of the effect of the heat pump on the operation mode of the thermal power plant. In this work we analyze the influence of the heat pumps inclusion in deaeration schemes of heating network make-up water on the operating modes of the CHP. All calculations were made for the real scheme of the de-aeration plant DSV-800 of the power unit with a T-100 turbine. The calculations were carried out for three schemes of heat pumps of different capacities. The calculations took into the account various uses of the heat received from the heat pumps.
\end{abstract}

\section{Introduction}

High energy intensity of product manufacturing requires qualitative changes in the energy sector. TPPs should reduce unit costs of fuel equivalent for the generation of electricity and heat. [1]. This can be achieved by introducing facilities for the disposal of waste heat and its transfer it to the cycle, for example, heat pumps (HP). HP working technology is known from the nineteenth century, from the second half of the twentieth century they have been used on a large-scale abroad. [2,3,4]. In Russia up to date HPs are still considered "exotic" due to the preference of traditional cogeneration work cycles. The idea of HP application at cogeneration cycle looks beneficial at first glance but requires analysis of its effect on the operation modes of the TPP. Many Russian scientists worked on the application of heat pumps at TPPs, including V.P. Protsenko [5-7], E.E. Shpilrain [8], A.I. Andryushchenko [9-11], V.M. Borovkov [12-14] and others. Most of the works were focused on the analysis of TPPs with HP without taking into account its influence on the operating conditions of the thermal station. Therefore the aim of this work was to evaluate the influence of heat pumps inclusion in deaeration scheme of heating network make-up water on the operating modes of the TPP.

In order to achieve this goal, it is necessary to solve the following tasks:

1) to simulate the real deaeration installation scheme of make-up water of DSV-800 heat network as part of a power unit with T-100 turbine;

2) to propose a scheme for switching HP for heating the make-up water of the heat network;

\footnotetext{
*Corresponding author: ia.88@mail.ru
} 
3) to evaluate the influence of the inclusion of a HP on the operation mode of a real steam-turbine plant with the help of the simulation method;

4) to analyze the influence of the HP on the economic efficiency of the steam turbine plant.

\section{Methods}

We applied simulation methods to analyze the influence of HP on the operating modes of a steam turbine plant. The simulation was carried out on CAD software "United Cycle" (Russia). CAD "United Cycle" is based on an algorithm that allows determining characteristics of power plants with technological schemes of any complexity for various modes of operation of main and auxiliary equipment. [15,16,17]. Fig. 1 shows the flow scheme of a mathematical model of a power unit with a T-100 turbine with a system of make-up water heating in a vacuum deaerator DSV-800. Using this scheme as an example, we will consider how heat pump system will affect TPP's operation mode.

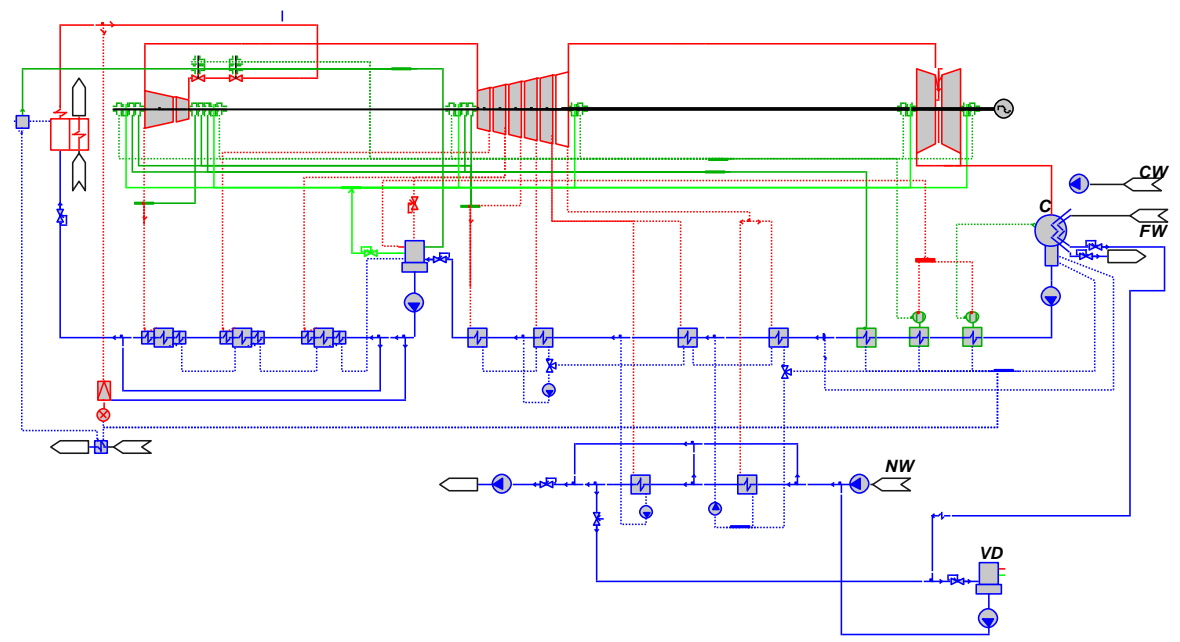

Fig. 1. Scheme of heating of make-up water in the vacuum deaerator for the power unit with T100 turbine : C - condenser, CW - cooling water, FW - make-up water of the heating network, NW - network water, VD - vacuum deaerator.

For DSV-800 vacuum deaerator heating medium is water of high potential, with a temperature around $95-105^{\circ} \mathrm{C}$. Heating of water in vacuum deaerator's compartments is determined by the following formula:

$$
\lg \frac{t_{s}-t_{\text {in }}}{t_{S}-t_{\text {out }}}=A_{1} L \sqrt[3]{\frac{1}{d_{0}}\left(\frac{w_{S t}}{w_{0}}\right)^{2}}
$$

where $t_{s}$ - is saturation temperature at vacuum deaerator pressure, ${ }^{\circ} \mathrm{C}$;

$t_{\text {in }}, t_{\text {out }}$ - water temperature at the inlet and outlet of the compartment, ${ }^{\circ} \mathrm{C}$;

$L, d_{0}$ - the length of the jets and the diameter of the hole in the plate, $\mathrm{m}$;

$w_{s t}$ - average steam velocity in the bundle of pipes, $\mathrm{m} / \mathrm{s}$;

$w_{0}$ - average velocity of the water outflow from the hole in the plate, $\mathrm{m} / \mathrm{s}$;

$A_{1}$ coefficient is determined depending on the pressure and temperature of the source water. The closer $t_{s}$ and $t_{i n}$ values are the greater would be the length of the jets in the plate of the deaeration unit. In this regard, the minimum water heating in DSV-800 deaerator is $15^{\circ} \mathrm{C}$. 
According to Fig. 1 make-up water of the heating network is first heated in the integrated bundles of the steam turbine condenser, and then is fed to the de-aerator. Therefore, the optimal scheme for switching on the heat pump will be its connection after the built-in bundles of steam turbine condensers before the vacuum deaerator (Fig. 2). Cooling water is selected as the source of low-potential heat at the outlet of the steam turbine condenser. The choice of cooling water in the reverse system of technical water supply as a LPH source will allow to reduce the amount of waste heat at the TPP, and also to lower the temperature of the circulating water at the entrance to the steam turbine, and as a consequence, to deepen the vacuum in its condenser.

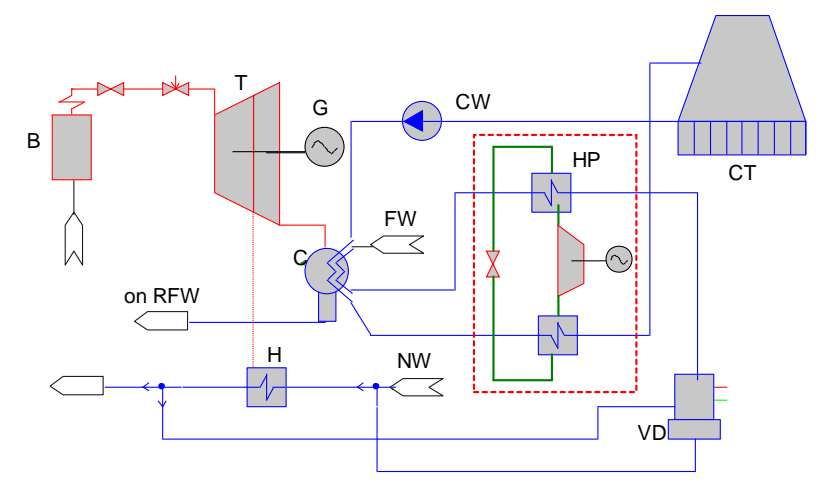

Fig. 2. The scheme of applying HP for heating the make-up water: B - boiler, T - turbine, G electric generator, CW - cooling water, CT - cooling tower, HP - heat pump, FW - makeup water of the heating network, $\mathrm{C}$ - condenser, RFW - regenerative system of make-up water heating, $\mathrm{H}$ - network water heater, NW - network water, VD - vacuum deaerator

For calculations, we choose the following initial data as the base mode (without HP application):

1. The consumption of the make-up water of the heat network is $194.4 \mathrm{~kg} / \mathrm{s}$ (an opentype heat supply system), its temperature after the built-in bundles of steam turbine condensers is $25^{\circ} \mathrm{C}$.

2. The pressure in the vacuum deaerator is $0.2 \mathrm{bar}$, the drain temperature from DSV -800 is $60^{\circ} \mathrm{C}$, the maximum temperature of the make-up water at the inlet to the deaerator is 45 ${ }^{\circ} \mathrm{C}$. $\mathrm{kg} / \mathrm{s}$.

3. The temperature of the heating water for DSV -800 is $100^{\circ} \mathrm{C}$, its flow rate is 170.9

4. Generation of electricity at the generator terminals is $100 \mathrm{MW}$.

5. The heat output from the heating plant (total heat capacity of the network heaters and built-in beam) is $194 \mathrm{MW}$.

6. The consumption of gaseous fuel burned in the boiler plant is 35.47 thousand $\mathrm{Nm} 3 / \mathrm{h}$.

The inclusion of HP for heating the make-up water of the heating network will change the mode of operation of the power plant in many respects. Positive and negative changes in the mode of operation of the power plant when HP is included in the scheme for deaeration of the make-up water of the heating network are summarized in Table 1.

The main factor influencing the efficiency of joint operation of TPP and HP is the choice of heat application. The article considered three options for using heat received from the HP. [18]:

1) for additional production of electrical energy $(\uparrow \mathrm{Ne})$. At the same time, the heat output from the TPP and the total fuel consumption do not change;

2 ) to increase the heat supply from the TPP ( $\uparrow \mathrm{Qt})$. At the same time, the total electric load of the TPP and the total consumption of the burned fuel remain unchanged; 
3) to reduce fuel consumption ( $\downarrow$ Bp), burned in the boiler. At the same time, the total power generation and heat supply from the TPP remain unchanged.

Calculations were made for HP of various capacities (tempering heat from the HP condenser) for three ways of using heat from them. HP capacity (QHP) was $16.3 \mathrm{MW}, 12.2$ MW and 8.1 MW, and was selected in such a way as to heat the make-up water of the heating network after the built-in capacitor bank to a temperature of $45^{\circ} \mathrm{C}, 40^{\circ} \mathrm{C}$ and $35^{\circ}$ $\mathrm{C}$, respectively.

The effectiveness of HP inclusion in the deaeration plant was calculated by comparing the revenue generated by HP with additional heat or power generation and reducing fuel consumption, with increased energy costs for the HP compressor drive, circulating and condensate pumps. All calculations were made for the simplest scheme of HP vapor compression. For all the options considered, the difference between the temperature in the $\mathrm{HP}$ evaporator and the temperature in its condenser was less than $33^{\circ} \mathrm{C}$, so the operation of such an installation is effective, and the COP values varied from 4.9 to 7 in different modes $[19,20,21]$. For calculations, we used reference data of PJSC "TGC-1" tariffs for heat, purchase and sale of electricity in 2018.

Table 1. - Main changes in the mode of operation of the power plant when HP is included in the scheme for deaeration of the make-up water of the heating network.

\begin{tabular}{|l|l|}
\hline \multicolumn{1}{|c|}{ Positive changes } & \multicolumn{1}{|c|}{ Negative changes } \\
\hline $\begin{array}{l}\text { Reducing of high potential water flow, } \\
\text { taken for the vacuum deaerator }\end{array}$ & $\begin{array}{l}\text { Increase in steam flow rate into the } \\
\text { steam turbine condenser and, as a } \\
\text { consequence, increasing the flow rate } \\
\text { of the circulating water }\end{array}$ \\
\hline $\begin{array}{l}\text { Reducing the flow of network water } \\
\text { through network heaters }\end{array}$ & $\begin{array}{l}\text { Increased power of the circulation } \\
\text { pumps }\end{array}$ \\
\hline $\begin{array}{l}\text { Reducing the flow rate of selected } \\
\text { steam with a high value of } \\
\text { underproduction coefficient }\end{array}$ & $\begin{array}{l}\text { Increased flow rate of the main } \\
\text { condensate at the output of the steam } \\
\text { turbine condenser }\end{array}$ \\
\hline $\begin{array}{l}\text { Reducing the power of the pumps of the } \\
\text { make-up water of the heating network }\end{array}$ & $\begin{array}{l}\text { Increased power of the condensate } \\
\text { pump }\end{array}$ \\
\hline $\begin{array}{l}\text { Possibility of: } \\
\text {-decreasing fuel consumption; } \\
\text {-increase in electricity generation; } \\
\text {-increase in heat release. }\end{array}$ & $\begin{array}{l}\text { Higher costs for TPP own energy } \\
\text { needs }\end{array}$ \\
\hline
\end{tabular}

\section{Results and Discussion}

A comparison of hourly profit for HPs of different capacities for the three options of heat usage is shown in Fig. 3. 


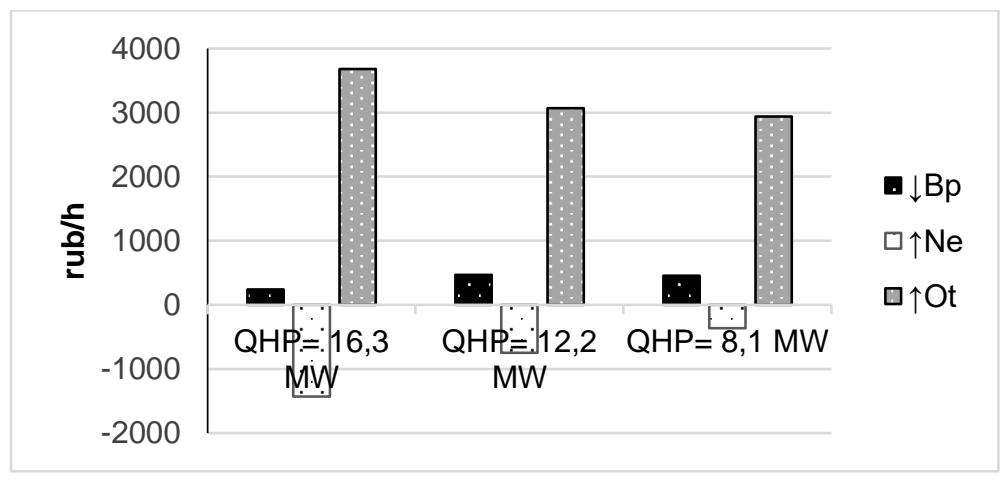

Fig. 3. Hourly profit for HPs of different capacities for the three options of heat usage.

Analysis showed that the greatest profit is achieved when HP is switched on with a heat release of 16.3 MW when it is used to increase the heat output from the TPP. This scheme allows to save up to 10.6 million rubles per quarter. Applying HP for additional power generation will be unprofitable. For such a scheme, the cost of the HP drive exceeds the amount of additional power generated at the terminals of the steam turbine generator.

\section{Conclusions}

The real scheme of the deaeration plant of make-up water of DSV-800 heat network as a part of the power unit with the T-100 turbine was simulated. For this power unit, a scheme for switching on a heat pump for heating the make-up water of the heating network after the built-in bundles of the steam turbine condenser before the vacuum deaerator is proposed. The analysis of the effect of the heat pump on the operating mode of the real steam turbine plant showed the advantage of the scheme of the inclusion of the high-power heat pump (heat output $16.3 \mathrm{MW}$ ) for additional heat production at the station. Applying such a scheme allows saving up to 10.6 million rubles quarterly.

\section{References}

1. I.D. Anikina, V.V. Sergeev, St. Petersburg State Polytechnic University Journal of Engineering Science and Technology, 3 (178), 56-61 (2013)

2. I.D. Anikina, V.V. Sergeev, N.T. Amosov, M.G. Luchko, Int. Sc. Journal for Altern. Energy and Ecology, 3-4 (191-192), 9-49 (2016)

3. M.A. Molodkina. St. Petersburg State Polytechnic University Journal of Engineering Science and Technology, 2 (123), 81-85 (2011)

4. M.A. Molodkina, St. Petersburg State Polytechnic University Journal of Engineering Science and Technology, 3 (130), 84-88 (2011)

5. V.P. Protsenko, S. B. Pustovalov, En. saving and water treat., 1(63), 25-29 (2010)

6. I.M. Kalnin, V.P. Protsenko, S.B. Pustovalov, Refrig. Equip., 1, 20-22 (2011)

7. V.P. Protsenko, A.A. Zaitsev, V.N. Starshinin, Heat Recovery Syst. and CHP, 3(12), 241-245 (1992)

8. E. E Shpilrayn, Thermal Engineering, 7, 54-56 (2003)

9. A.I. Andryushchenko. Thermal Engineering, 5, 2-6, (1997)

10. A.I. Andryushchenko. ,Industrial Power Engineering, 6, 2-4 (1997)

11. A.I. Andryushchenko, D.V. Novikov, Energy problems, 11-12, 17-25 (2004) 
12. V.M. Borovkov, A.Al. Alavin, Industrial Power Engineering, 8, 40-43 (2007)

13. V.M. Borovkov A.Al. Alavin, Energy problems, 7-8, 12-21(2006)

14. V.M. Borovkov A.Al. Alavin, Energy problems, 1-2, $42-46$ (2007)

15. S. Romanov, A. Kutakhov, N. Zhuk, O. Demidov, K. Romanov. ECOS-2003, 16911696 (2003)

16. O. Demidov, A. Kutakhov, S. Romanov, ECOS-2003, 1697-1704 (2003)

17. O.I. Demidov, N.I. Zhuk, V.A. Ivanov, V.M. Koren, A. G. Kutakhov, S. N. Romanov, Proceedings of SPbGTU «Power machines and plants», 481, 115-123 (1999)

18. I.D. Anikina, V.V. Sergeyev, N.T. Amosov, M.G. Luchko. Inter. Journal of Hydrogen Energy, 42, 636-642 (2017)

19. M. Taylor, REHVA Journal, 48 (4), 13-15 (2011)

20. V.D. Burov, A.A. Dudolin, I.P. Ilyina, E. Oleynikova, A. Sedlov, N. "MPEI Vestnik" Journal, 3, 44-50 (2013)

21. A. Fedyukhin, I. Sultanguzin, A. Gyul'Maliev, V. Sergeev, Eurasian Chem.-Techn. Journal, 19 (3), 245-253 (2017) 